\title{
Accumulated Human Capital, Unemployment, And Subsequent Wages
}

Vera Adamchik, (Email: adamchikv@uhv.edu), University of Houston, Victoria Thomas Hyclak, (e-mail: tjh7@lehigh.edu), Lehigh University

\begin{abstract}
The objective of this paper is to empirically examine the determinants of post-unemployment wages and to identify the underlying economic forces triggering the observed wage setting mechanisms. Specifically, the paper focuses on the impact of accumulated human capital on post-unemployment wages and investigates the following issues: (1) Is formal educational attainment a significant determinant of post-unemployment wages? (2) What type of previous labor market experience (general vs. job-specific) is more valued by a new employer? (3) Are workers who find a new job in the same sector, industry or occupation more likely to retain their specific human capital and, thus, earn higher post-unemployment wages? The 1994-2001 Polish Labor Force Surveys are used as the data source for this study.
\end{abstract}

\section{INTRODUCTION}

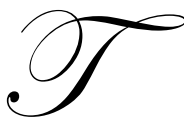

he transformation to a market economy in the countries of Central and Eastern Europe and in particular in Poland has been accompanied by significant labor reallocation and the resulting appearance of persistent unemployment. Prior to 1989 there was no official unemployment in Poland. Soon after the first wave of reforms in 1990, the unemployment rate rose to 6 percent. It peaked at 17 percent in 1994, steadily declined to about 10 percent in 1998 and then started to rise again, reaching 18 percent in the new millennium.

In the last decade, a number of empirical research studies of persistent unemployment in Poland have been published. These studies mainly focus on unemployment duration and transitions into and from unemployment. Recently, however, the focus of microeconomic research on unemployment has been shifting towards the economic consequences of an unemployment experience. The erosion of human capital, the loss of job-specific skills, the downward revision of reservation wages, the social stigmas and stereotyping attached to unemployment are believed to negatively affect post-unemployment wages. Despite an extensive body of research on this topic in developed countries, so far little research has been done in this area for transition economies. The objective of this paper is to empirically examine the determinants of post-unemployment wages in a transition economy, namely Poland, and to identify the underlying economic forces triggering the observed wage setting mechanisms.

The unemployed face a labor market that tries to infer their ability from their current publicly observed characteristics as well as past performance. Broadly speaking, accumulated human capital is one of the major factors that appear to be particularly relevant. That is why this paper focuses on the impact of accumulated human capital on post-unemployment wages and investigates the following specific issues: (1) Is formal educational attainment a significant determinant of post-unemployment wages? (2) What type of previous labor market experience (general vs. job-specific) is more valued by a new employer? (3) Are workers who find a new job in the same sector, industry or occupation more likely to retain their specific human capital and, thus, earn higher post-unemployment wages? We examine these issues for men and women separately, because it is quite possible that the labor market mechanisms through which unemployment affects future earnings differ across socio-demographic groups.

This paper contributes to the literature on post-unemployment wages in several ways. First, in contrast to many previous studies that primarily focus on wage losses by comparing re-entry wages of unemployed individuals 
with their pre-unemployment wages or with the wages of employed workers with similar characteristics, this study concentrates on the factors affecting accepted wages of those people who experienced a spell of unemployment. Our approach has its advantages in that it considers all unemployed individuals, not only those with previous work experience, and assesses the impact of various pre-unemployment and unemployment characteristics on accepted wages in addition to the impact of current job characteristics. Second, many published research papers suffer from a lack of suitable data and, thus, use a very limited number of variables and even impute variables. This, undoubtedly, reduces the reliability and trustworthiness of obtained findings. Our study uses a rich data set derived from the Polish Labor Force Surveys (LFS) that provide us with numerous characteristics of an individual not only in their new job, but also during an unemployment spell as well as prior to it. In addition to wages, the Surveys provide us with information on the reported reservation wages, which is quite rare. Third, to our knowledge, it is the first paper analyzing this subject matter for a transition labor market in Poland.

An examination of post-unemployment earnings is carried out within a basic job search and human capital theory framework. While special focus is placed on post-unemployment acceptance wages, the basic search theory framework prompts us to expand our analysis to the determinants of the reservation wage and the probability of reemployment for those out of work.

The paper is organized as follows. Section 2 explains the data set that we use. Section 3 describes the methodology. In Section 4 we report our findings and speculate on the factors that might drive the results. Section 5 summarizes the paper, and suggestions for future research conclude the paper.

\section{DATA SOURCE}

Labor Force Surveys which are conducted by the Polish Central Statistical Office every three months (February, May, August, and November) constitute the data source in this study (see Socha and Weisberg, 1999 for a comprehensive assessment). The observations belong to the 1994-2001 period. The LFS samples around 50,000 people over 15 years old without an upper age limit, covering approximately 0.2 percent of the Polish population over 15 years old. Each person is observed four times: at the moment of the initial meeting and then at 3-, 12- and 15-month follow-up interviews. A survey consists of more than 60 questions. For each individual in each survey we have a variety of background personal (gender, marital status, education, employment history), household (household income, position in the household) and environmental (local labor market conditions) characteristics. Survey questions allow us to distinguish employed and unemployed individuals as well as those who are not in the labor force according to the ILO definitions. Unfortunately, the quarterly periodicity of the LFS and, in particular, the nine-month gap between an individual's second and third appearances in the survey, means that we cannot rule out the possibility of unrecorded changes in labor force status between observations. To minimize this potential inaccuracy, for each individual we consider only those observations that are one quarter apart. In our sample, the earliest group of the unemployed was interviewed in February 1994 and the follow-up interview was in May 1994; and the latest group was interviewed in November 2000 and the follow-up interview was in February 2001.

We first identify all unemployed individuals, and then we identify their labor market statuses in the next survey. Those individuals who moved from unemployment to employment constitute our sample of postunemployment wage earners. According to the Polish LFS design, wages are recorded only if a person works as a fulltime hired employee. Full-time hired individuals answer the question "What were your net monthly earnings at the main workplace during the preceding month?" We consider the answer to this question as an individual's postunemployment acceptance wage. Further, all unemployed individuals in the survey answer the question: "What is the lowest net monthly pay at which you would be willing to accept a new job?" We consider the answer to this question as an expression of an individual's reservation wage.

There might be some concerns about the reliability of self-reported earnings. In addition to the LFS, there are two other major sources of earnings data on the Polish labor market: firm reports to the Central Statistical Office and the Household Budget Survey (see Socha and Weisberg, 1999). The similarity in findings obtained by different researchers using all three sources suggests that the earnings data in the LFS are at least as accurate and reliable as those from the HBS or firm reports. Similarly to wages, questions are often raised about the reliability of self-reports 
on reservation wages. Recent research (see, for example, Schmidt and Winkelmann, 1993; Boeri, 2001; Prasad, 2003), however, gives us confidence that we can use the available data in empirical analyses of job search in our sample. Our data seem to be in accordance with the findings in the mentioned studies.

In our data set, there were 38,954 unemployed individuals at the moment of the first observation who were not full-time students, or handicapped, or younger than 18, or older than 65 for men and 60 for women. These age restrictions correspond to the different retirement ages for men and women as well as comply with the Polish Central Statistical Office's definition of the working age population. Of 38,954 unemployed individuals, 6,133 found a job, 3,276 dropped out of the labor force and 29,545 were still unemployed one quarter later. Among those who found a new job, 3,207 people were full-time hired employees with reported post-unemployment wages; and the rest were self-employed, or assisting members in a family business, or part-time hired workers.

Finally, since the observations in our sample belong to 1994-2001, reported net reservation and accepted wages were deflated to February 1994 by using monthly inflation rates (during the period under consideration, the average price level in Poland increased by 170 percent).

\section{METHOD}

\section{Theoretical Framework And Methodology}

The underlying theoretical model is as follows:

$\ln W_{i}=\beta^{\prime} X_{i}+\varepsilon_{i}$

where $\ln W$ is the logarithm of the accepted net monthly wage; $X$ is a vector of wage determining variables; and $\varepsilon$ is an error term. The fact that we observe accepted wages for only those men and women who are currently working as full-time hired employees may cause the problem of potential selectivity bias in the estimation of wage equations. If selection into labor market states is non-random, our analysis based on Eq. (1) may give us biased estimates. To account for self-selectivity, we augment our model with Eq. (2) describing the self-selection mechanism into different labor market states to which an unemployed individual may exit:

$Z_{i}^{*}=\gamma^{\prime} K_{i}+u_{i}$

where $Z^{*}$ is not observed; $Z$ is its observed counterpart indicating one of the possible labor market states to which an exit from unemployment has occurred; $K$ is a vector of characteristics that explain a person's decision to select themselves into a certain labor market state; and $u$ is an error term.

The drawback of Eq. (2) used as a selection mechanism is that it emphasizes the chance character of a movement between labor market states. In this study, we try to incorporate the behavior of the unemployed into our model of accepted wages. Using the job search theory framework, we are trying to stress the choice element in each transition: people occupy the state that they prefer, given their opportunities. According to the simple search model developed by McCall (1970), each unemployed individual is assumed to choose a specific reservation wage so as to equate the marginal cost and the expected marginal benefit of continued search. If a person actually follows the optimal decision rule, such a person leaves unemployment if and only if they receive a new wage offer and that wage exceeds their reservation wage. Thus, the probability of leaving unemployment is a function of the job offer arrival rate and the reservation wage. A conventional approach in the search literature states that any variable influencing the cost of search affects an individual's reservation wage but does not have any impact on an employer's evaluation of this person. Taking a cue from this, we write down the following self-selection mechanism, which is now determined by two simultaneous equations. The first equation models a person's reservation wage; and the second equation models the probability of exiting to different labor market states as a function of a job offer arrival rate and the reservation wage: 


$$
\left\{\begin{array}{l}
\ln R W_{i}=\delta_{1}^{\prime} K_{1 i}+\delta_{2}^{\prime} K_{2 i}+\zeta_{i} \\
Z_{i}^{*}=\gamma_{1}^{\prime} K_{1 i}+\gamma_{2} \ln R W_{i}+u_{i}
\end{array}\right.
$$

where $\ln R W$ is the logarithm of the reported net monthly reservation wage; $K_{1}$ is a vector of variables that affect the job offer arrival rate; $K_{2}$ is a vector of variables that affect an individual's reservation wage but do not have any impact on an employer's decision to hire; and $\zeta$ and $u$ are the error terms.

\section{The Estimation Procedure}

The quasi-structural approach adopted in this study has the obvious advantage of not needing strong functional form assumptions on the wage offer distribution. While quite parsimonious, it, nevertheless, allows us to distinguish between the determinants of the arrival rate of job offers and the acceptance rate.

\section{Reservation Wage Equation}

Under our assumption about the exogeneity of all variables in $K_{1}$ and $K_{2}$, Eq. (3-a) can be estimated consistently and efficiently by OLS. We understand that this assumption is somewhat restrictive because the reservation wage and the duration of an unemployment spell (which is included into the reservation wage equation) are determined simultaneously. We, nevertheless, adopt this simplifying assumption in order to achieve the identifiability of our model.

We consider receipt of unemployment benefits and the availability of other sources of non-wage monetary personal and household income as the variables that affect the reservation wage only. One can argue that unemployment benefits tend to imply more frequent visits to Labor Offices and hence affect the job search effort and the job offer arrival rate, if not its distribution. However, it is well documented in the literature that in Poland Labor Offices do not substantially affect the chance of re-entering into employment and are regarded by the unemployed primarily as a source of benefits.

\section{Selection Equation}

We use an ordered probit model as the self-selection mechanism in Eq. (3-b). We order the six different states to which an unemployed individual may exit according to the increasing strength of attachment to the labor market or, in other words, according to the increasing number of hours spent in the labor market either working or searching for a job: $0=$ not in the labor force, $1=$ unemployed, $2=$ part-time hired employee, $3=$ assisting family member in a family business, $4=$ self-employed, $5=$ full-time hired employee. In ordering the labor market states, we rely upon our calculations performed for five Labor Force Surveys evenly spaced throughout the period under consideration. Our calculations show that in a week of a survey part-time hired employees work on average 24-28 hours, assisting family members - 26-38 hours, self-employed individuals - 38-41 hours, and full-time hired employees - 41-43 hours. In addition, the proportion of employees who work 40 or more hours per week on a regular basis is, respectively, 7-21, 36-60, 74-87, and 92-94 percent.

We first estimate the parameters in Eq. (3-a) and compute $\ln \hat{R} W$. We then insert $\ln \hat{R} W$ into Eq. (3-b) and estimate its parameters by maximum likelihood. The decision to use the predicted reservation wage instead of the actual reservation wage in the selection equation is driven by some possible endogeneity of the reservation wage with respect to a worker's expected labor market status. Consistent and efficient estimates of Eq. (3-b) as well as the corrected asymptotic covariance matrix may be obtained using a two-step MLE procedure suggested by Murphy and Topel (1985) and Greene (1997, pp.140-142).

Before we proceed, we have to mention an identification issue. At the very least to achieve identification of the selection equation, we need one variable that influences the choice of the labor market state but may be excluded 
from the accepted wage equation. To achieve this identification, we include variables reflecting a person's position in the household in the selection equation. In addition, we include the age variable in the probit equation, while the potential experience variable appears in the wage equation.

Accepted wage equation. We now turn to the equation of our interest, namely Eq. (1). LnW is observed only when $Z=5$. Following Greene (1997, p. 977) we can write down the model that applies to the observations in our sample:

$\ln W_{i} \mid \ln W_{i}$ is observed $=E\left[\ln W_{i} \mid Z_{i}=5\right]+v_{i}=\beta^{\prime} X_{i}+\beta_{\lambda} \lambda_{i}+v_{i}$

where $\lambda$ is a correction term derived from the employment status regression to control for selection bias since our sample here is restricted to those who found full-time hired jobs after an unemployment spell, and $v$ is an error term. Having estimated the ordered probit by maximum likelihood using all observations, we then select only those observations for which the accepted wages are observed and compute $\hat{\lambda}_{i}$ for each of them. We estimate $\beta$ and $\beta_{\lambda}$ by OLS regression of $\ln W$ on $\mathrm{X}$ and the correction term $\hat{\lambda}$. However, even if $\lambda_{i}$ were observed, OLS would be inefficient because the disturbance $v_{i}$ is heteroscedastic. Hence, we complete the estimation procedure by correcting the estimated asymptotic covariance matrix of the estimates as suggested in Heckman (1979) and Greene (1981).

\section{RESULTS}

The description and list of variables are presented in Appendices 1, 2, and 3. Table 1 shows coefficient estimates of the determinants of the wage received by male and female workers in their initial job after a period of unemployment. The sets of results correspond to Eq. (4). Given our estimation strategy, it is important to note that the influence of variables that enter into the reservation wage and transition regressions are also captured in the acceptance wage regressions indirectly through $L A M B D A$. The results for men and women are quite different; thus, while discussing the estimation results, we are concerned with the performance of men and women relative to each other.

Table 1: Post-Unemployment Wage Equation: Equation (4). Variables, Their Means, Estimated Coefficients And Standard Errors (Dependent Variable Is The Log Real Net Monthly Accepted Wage)

\begin{tabular}{|c|c|c|c|c|c|c|}
\hline & \multicolumn{2}{|c|}{ Means } & \multicolumn{2}{|c|}{ Men } & \multicolumn{2}{|c|}{ Women } \\
\hline & Men & Women & Co-efficient & $\begin{array}{c}\text { Standard } \\
\text { Error }\end{array}$ & Co-efficient & $\begin{array}{c}\text { Standard } \\
\text { Error }\end{array}$ \\
\hline (A) & (1) & (2) & (3) & (4) & (5) & $(6)$ \\
\hline CONSTANT & 1.000 & 1.000 & 5.208 & $(0.188)$ & 4.587 & $(0.261)$ \\
\hline MARRIED & 0.509 & 0.565 & 0.054 & $(0.023)$ & -0.063 & $(0.036)$ \\
\hline HIGHER & 0.034 & 0.104 & 0.096 & $(0.061)$ & 0.218 & $(0.067)$ \\
\hline SECVOC & 0.157 & 0.280 & 0.054 & $(0.028)$ & 0.126 & $(0.047)$ \\
\hline SECGEN & 0.022 & 0.110 & 0.041 & $(0.057)$ & 0.073 & $(0.051)$ \\
\hline BASICVOC & 0.555 & 0.355 & 0.038 & $(0.021)$ & 0.062 & $(0.040)$ \\
\hline POTEXP & 14.408 & 12.752 & 0.004 & $(0.004)$ & 0.015 & $(0.006)$ \\
\hline POTEXPSQ & 312.323 & 265.164 & -0.000 & $(0.000)$ & -0.000 & $(0.000)$ \\
\hline LnTUNEMPL & 1.975 & 2.153 & -0.043 & $(0.008)$ & -0.004 & $(0.012)$ \\
\hline LOSER & 0.673 & 0.540 & -0.081 & $(0.024)$ & -0.004 & $(0.034)$ \\
\hline LASTPRV & 0.479 & 0.403 & 0.089 & $(0.043)$ & 0.087 & $(0.058)$ \\
\hline LASTPUB & 0.341 & 0.310 & 0.114 & $(0.045)$ & 0.058 & $(0.060)$ \\
\hline
\end{tabular}




\begin{tabular}{|c|c|c|c|c|c|c|}
\hline TENURE1_4 & 0.499 & 0.421 & 0.054 & $(0.027)$ & -0.032 & $(0.045)$ \\
\hline TENURE5_9 & 0.096 & 0.100 & 0.075 & $(0.037)$ & -0.010 & $(0.058)$ \\
\hline TENURE10_ & 0.107 & 0.112 & 0.032 & $(0.037)$ & -0.037 & $(0.057)$ \\
\hline SIZE6_20 & 0.333 & 0.234 & 0.031 & $(0.022)$ & 0.052 & $(0.033)$ \\
\hline SIZE21_50 & 0.195 & 0.177 & -0.008 & $(0.026)$ & 0.047 & $(0.038)$ \\
\hline SIZE51_100 & 0.087 & 0.095 & 0.033 & $(0.033)$ & 0.057 & $(0.046)$ \\
\hline SIZE100_ & 0.140 & 0.158 & 0.130 & $(0.031)$ & 0.100 & $(0.041)$ \\
\hline PERMAN & 0.656 & 0.682 & 0.041 & $(0.017)$ & 0.058 & $(0.025)$ \\
\hline CHNGED_SEC & 0.257 & 0.233 & -0.022 & $(0.021)$ & -0.042 & $(0.032)$ \\
\hline CHNGED_IND & 0.438 & 0.362 & -0.016 & $(0.020)$ & -0.000 & $(0.031)$ \\
\hline CHNGED_OCC & 0.368 & 0.362 & -0.003 & $(0.020)$ & -0.006 & $(0.030)$ \\
\hline CURPRV & 0.713 & 0.686 & 0.114 & $(0.025)$ & 0.049 & $(0.038)$ \\
\hline AGRIFISH & 0.053 & 0.043 & -0.117 & $(0.061)$ & -0.016 & $(0.092)$ \\
\hline MINING & 0.009 & 0.003 & 0.055 & $(0.091)$ & -0.120 & $(0.206)$ \\
\hline MANUF & 0.268 & 0.292 & -0.031 & $(0.044)$ & -0.023 & $(0.060)$ \\
\hline CONSTR & 0.284 & 0.012 & 0.065 & $(0.044)$ & 0.118 & $(0.114)$ \\
\hline ENERTRANSP & 0.062 & 0.024 & 0.066 & $(0.051)$ & -0.043 & $(0.088)$ \\
\hline TRADEHOTEL & 0.134 & 0.338 & 0.008 & $(0.047)$ & 0.021 & $(0.056)$ \\
\hline FINESTATE & 0.035 & 0.044 & -0.093 & $(0.059)$ & 0.033 & $(0.072)$ \\
\hline ADEDHEC & 0.115 & 0.187 & -0.078 & $(0.047)$ & -0.056 & $(0.056)$ \\
\hline TOPMANAGER & 0.008 & 0.005 & 0.472 & $(0.093)$ & 0.409 & $(0.167)$ \\
\hline SPECIALIST & 0.015 & 0.049 & 0.356 & $(0.083)$ & 0.314 & $(0.068)$ \\
\hline TECHNICIAN & 0.034 & 0.103 & 0.173 & $(0.049)$ & 0.122 & $(0.050)$ \\
\hline OFFICE & 0.036 & 0.109 & 0.039 & $(0.046)$ & 0.102 & $(0.049)$ \\
\hline SERVICE & 0.061 & 0.322 & 0.027 & $(0.039)$ & 0.053 & $(0.046)$ \\
\hline FARMER & 0.030 & 0.026 & 0.139 & $(0.062)$ & 0.119 & $(0.102)$ \\
\hline INDUSTRIAL & 0.413 & 0.163 & 0.067 & $(0.021)$ & 0.053 & $(0.046)$ \\
\hline MACHINIST & 0.138 & 0.034 & 0.111 & $(0.028)$ & 0.057 & $(0.069)$ \\
\hline LnURATE & 2.513 & 2.506 & -0.045 & $(0.037)$ & -0.030 & $(0.054)$ \\
\hline CITY100_ & 0.191 & 0.209 & 0.042 & $(0.025)$ & 0.056 & $(0.037)$ \\
\hline CITY20_100 & 0.201 & 0.218 & 0.006 & $(0.023)$ & -0.008 & $(0.031)$ \\
\hline CITY_20 & 0.165 & 0.184 & -0.023 & $(0.023)$ & 0.001 & $(0.032)$ \\
\hline Y1995 & 0.210 & 0.184 & 0.028 & $(0.024)$ & 0.050 & $(0.036)$ \\
\hline Y1996 & 0.166 & 0.177 & 0.053 & $(0.026)$ & 0.059 & $(0.037)$ \\
\hline Y1997 & 0.158 & 0.157 & 0.090 & $(0.029)$ & 0.141 & $(0.039)$ \\
\hline Y1998 & 0.122 & 0.139 & 0.143 & $(0.037)$ & 0.192 & $(0.042)$ \\
\hline Y1999 & 0.014 & 0.016 & 0.234 & $(0.072)$ & 0.288 & $(0.092)$ \\
\hline Y2000 & 0.097 & 0.109 & 0.195 & $(0.034)$ & 0.197 & $(0.046)$ \\
\hline SPRSUM & 0.574 & 0.520 & 0.012 & $(0.023)$ & 0.028 & $(0.024)$ \\
\hline LAMBDA & 1.557 & 1.827 & 0.047 & $(0.102)$ & 0.205 & $(0.127)$ \\
\hline R-squared & & & 0.222 & & 0.237 & \\
\hline N obs. & & & 1921 & & 1286 & \\
\hline
\end{tabular}




\section{Selection Bias}

The selection control variable $L A M B D A$ term is included to adjust for non-observable wages of those who do not work or do not report earnings. For men, the coefficient estimate on LAMBDA is near zero (0.047) and not statistically significant. On the other hand, for women, the coefficient estimate on the selection control variable is positive, of a greater magnitude (0.205), and significant (at the 11 percent level). This implies that selection bias may not be an important factor in the estimation of the acceptance wage regressions for male workers, while women seem to be positively selected and have higher wage offers than those not working full-time.

\section{Educational Attainment}

Table 1 shows significant differences in patterns of educational attainment. Unemployed women who found new jobs were better educated than men. The majority of newly employed women (about 50 percent) had university, post-secondary, or secondary vocational degrees, while the majority of newly hired men (about 56 percent) had only basic vocational education. It is worth noting that this educational pattern is rather traditional for Poland: men were encouraged to acquire basic vocational skills and enter the industrial and productive sphere of the labor market; on the other hand, women were more likely to acquire general and higher levels of education and enter the service sector.

In our model, schooling is represented by the level of educational attainment. The results in Table 1 indicate that acceptance wages of men and women were closely related to the usual educational attainment variables. The coefficients on levels of education are positive, generally statistically significant, and indicate that the wage return to schooling was higher for workers with more education, with the rates of return to all educational levels being higher for women. For instance, ceteris paribus, a woman with a university (secondary vocational) degree was offered a 21.8 (12.6) percent higher salary as compared to her least educated counterpart; for men these returns were significantly smaller -9.6 and 5.4 percent, respectively.

To analyze the dynamics of educational wage premia during transition, we split our sample into two subperiods: 1994-1996 (early transition) and 1997-2000 (mature transition) and estimated our full model (that is, Eqs. 3-a, 3-b, and 4) for each of them. Selected coefficients for Eq. (4) for these two periods are presented in Table 2. Now, we observe a noticeable reduction in the educational wage premia for women in the late 1990s. The estimated wage advantage from more schooling fell for women at all but one (basic vocational) educational levels. For instance, ceteris paribus, women with university diplomas earned 25.2 percent more than women with only an elementary education in 1994-1996 and 14.5 percent more in 1997-2000. Similarly, the rates of return for women with secondary vocational education fell from 13.9 percent to 9.7 percent. On the other hand, for men, the returns to university and secondary general levels of education significantly increased in 1997-2000. As a result, if in 1994-1996 the rates of return to all educational levels were higher for women, in 1997-2000 similarly educated men and women were more or less equally rewarded at their new jobs.

The causes of such a dramatic fall in the rates of return to education for the Polish women in the 1990s are yet to be explored. Generally, most of the change in earnings differentials between workers with different educational attainment can be explained by changes in the supply of and demand for skills (see Borland, 2000). Our calculations show that the labor supply of both men and women in Poland remained fairly stable over the period under consideration. Additionally, educational distributions of the male and female labor force slightly improved, but generally also remained quite stable. Thus, it seems that the supply of labor and its educational composition are not able to explain changes in relative earnings by education. Changes in the relative demand for skill categories appear to be mainly responsible for the dynamics of educational returns of men and women. It seems that highly educated Polish women were not in high demand. For example, the unemployment rate among the working age women with university diplomas increased from 2.9 to 6.1 percent from May 1994 to May 2001, with post-secondary education from 9.0 to 15.5 percent, with secondary general education - from 16.1 to 23.9 percent (for comparison, the unemployment rates for men also rose but at a slower pace). Hence, it appears that education acquired by women was devalued in a market economy. It may be due to the fact that men and women in Poland follow sharply divergent educational tracks. As a result, women are locked into a narrow array of outdated professions and occupations that are in lesser demand in an era of technological changes. 
Table 2. Selected Coefficients For Equation (4) For Two Sub-Periods: 1994-1996 And 1997-2000

\begin{tabular}{|c|c|c|c|c|c|c|c|c|}
\hline & \multicolumn{4}{|c|}{ Men } & \multicolumn{4}{|c|}{ Women } \\
\hline & \multicolumn{2}{|c|}{ 1994-1996 } & \multicolumn{2}{|c|}{ 1997-2000 } & \multicolumn{2}{|c|}{ 1994-1996 } & \multicolumn{2}{|c|}{$1997-2000$} \\
\hline & $\begin{array}{c}\text { Co- } \\
\text { efficient }\end{array}$ & $\begin{array}{c}\text { Standard } \\
\text { Error }\end{array}$ & $\begin{array}{c}\text { Co- } \\
\text { efficient }\end{array}$ & $\begin{array}{c}\text { Standard } \\
\text { Error }\end{array}$ & $\begin{array}{c}\text { Co- } \\
\text { efficient }\end{array}$ & $\begin{array}{c}\text { Standard } \\
\text { Error }\end{array}$ & $\begin{array}{c}\text { Co- } \\
\text { efficient }\end{array}$ & $\begin{array}{c}\text { Standard } \\
\text { Error }\end{array}$ \\
\hline MARRIED & 0.035 & $(0.028)$ & 0.075 & $(0.042)$ & -0.073 & $(0.047)$ & -0.033 & $(0.042)$ \\
\hline HIGHER & 0.075 & $(0.084)$ & 0.186 & $(0.101)$ & 0.252 & $(0.082)$ & 0.145 & $(0.087)$ \\
\hline SECVOC & 0.070 & $(0.038)$ & 0.051 & $(0.048)$ & 0.139 & $(0.057)$ & 0.097 & $(0.060)$ \\
\hline SECGEN & 0.015 & $(0.073)$ & 0.096 & $(0.100)$ & 0.087 & $(0.063)$ & 0.066 & $(0.063)$ \\
\hline BASICVOC & 0.044 & $(0.027)$ & 0.044 & $(0.036)$ & 0.053 & $(0.048)$ & 0.075 & $(0.051)$ \\
\hline POTEXP & 0.002 & $(0.005)$ & 0.010 & $(0.006)$ & 0.020 & $(0.007)$ & 0.010 & $(0.007)$ \\
\hline POTEXPSQ & -0.000 & $(0.000)$ & -0.000 & $(0.000)$ & -0.000 & $(0.000)$ & -0.000 & $(0.000)$ \\
\hline LnTUNEMPL & -0.043 & $(0.010)$ & -0.053 & $(0.013)$ & -0.015 & $(0.015)$ & 0.008 & $(0.014)$ \\
\hline LASTPRV & 0.110 & $(0.057)$ & 0.066 & $(0.068)$ & 0.104 & $(0.078)$ & 0.063 & $(0.063)$ \\
\hline LASTPUB & 0.129 & $(0.057)$ & 0.089 & $(0.079)$ & 0.071 & $(0.083)$ & 0.050 & $(0.066)$ \\
\hline TENURE1_4 & 0.049 & $(0.036)$ & 0.053 & $(0.043)$ & -0.056 & $(0.064)$ & 0.020 & $(0.046)$ \\
\hline TENURE5_9 & 0.079 & $(0.048)$ & 0.077 & $(0.063)$ & -0.038 & $(0.074)$ & 0.063 & $(0.075)$ \\
\hline TENURE10_ & 0.027 & $(0.047)$ & 0.019 & $(0.070)$ & -0.042 & $(0.078)$ & 0.002 & $(0.065)$ \\
\hline CHNGED_SEC & -0.042 & $(0.027)$ & -0.003 & $(0.039)$ & -0.084 & $(0.040)$ & 0.018 & $(0.039)$ \\
\hline CHNGED_IND & -0.018 & $(0.026)$ & 0.003 & $(0.035)$ & 0.025 & $(0.039)$ & -0.040 & $(0.038)$ \\
\hline CHNGED_OCC & -0.022 & $(0.025)$ & 0.023 & $(0.035)$ & -0.003 & $(0.038)$ & -0.006 & $(0.037)$ \\
\hline CURPRV & 0.194 & $(0.032)$ & -0.026 & $(0.044)$ & 0.066 & $(0.049)$ & 0.019 & $(0.047)$ \\
\hline $\mathrm{N}$ obs. & 1170 & & 751 & & 744 & & 542 & \\
\hline
\end{tabular}

NOTE: 1994 is the reference year in 1994-1996, and 1997 is the reference year for 1997-2000.

\section{Potential Labor Market Experience And Tenure}

In our model, potential work experience is defined as 'age minus years of education minus 6,' which is a rough measure of the number of years since an individual left school. To account for possible declining marginal returns to experience, the logarithm of the monthly wage is allowed to depend linearly on experience and squared experience. The coefficients on the POTEXP variables measure the returns to human capital accumulation accruing during potential time spent working. In our samples, potential labor market experience is a statistically significant determinant of acceptance wages only for women with the expected concave wage-experience profile: earnings rise due to rapid human capital accumulation in the early stage of a woman's labor market career, then peak somewhere about 26 years of experience, and then decline as hours worked and the incentive to invest in human capital decrease. While the wage effect of one additional year of potential work experience for women was 1.5 percent, the coefficient on experience squared $(-0.000294, t=-1.902)$ indicates that their returns were falling at a greater rate as compared to men for whom both coefficients are not statistically different from zero. Thus, it appears that if unemployed, women suffer from larger wage losses due to forgone accumulation than men do, ceteris paribus.

It is believed that specific human capital built up in the pre-unemployment job is totally or partly destroyed during the unemployment spell (Farber, 1997 interprets this phenomenon as economic redundancy of skills). The literature tries to assess the transferability of specific human capital by estimating the returns to tenure in the last job. In our study, the TENURE variable is used as a proxy for the specific human capital that a worker accumulated in their pre-unemployment workplace. Job tenure prior to unemployment was positively related to post-unemployment wages of men (although, only the coefficients for 1-4 and 5-9 years of tenure were statistically significant, which confirms the view that time spent in employment does not allow to access better paying jobs); while for women, the job tenure 
variables all had negative coefficients that were not significantly different from zero. Our findings for men may suggest that labor market experience accumulated prior to 1990 does not have any positive impact on postunemployment wages while experience gained during the transition period does. The latter results confirm the view (see, for example, Addison and Portugal, 1989) that previous tenure is also productive in new jobs, implying a partial transferability of job-specific human capital. In addition, for men, employers might view job tenure of 1-9 years prior to unemployment as an indicator of a potentially good employment match. This result has been seen in several studies of US workers (see, for example, Kletzer, 1989 and 1998). According to Kletzer, the tenure effect is mainly a reflection of unmeasured worker heterogeneity rather than accumulated employer-specific skills. If unmeasured characteristics of workers enhance their productivity and result in longer than average tenure profiles, then job tenure may be correlated with wages at different employers, even if the specific skills useful in the pre-displacement workplace have little value to the post-unemployment firm.

The pattern of results suggests that recent specific human capital gained with a given employer was important for men while general human capital gained through working experience was important for women. These findings are in accordance with the perception that women seem to invest more in general rather than specific human capital in order to make themselves less exposed to career interruptions and to ease movements in and out of the labor force. On the other hand, men with their high participation and employment rates seem to invest heavily in jobspecific human capital in order to ensure higher wages.

\section{A Switch Between Industries And Occupations}

A number of papers find that the post-displacement earnings of individuals who change industry are lower than earnings of those who stay in the same industry; similarly, the penalty for career interruptions is expected to be higher for those workers who change occupations (see Neal, 1995; a survey in Kletzer, 1998; Kriechel and Pfann, 2005). This may be seen as a consequence of a loss of industry- and occupation-specific human capital. The rationale is that industry- and occupation-specific skills are not transferable and hence do not increase a worker's productivity outside a particular industry or occupation. On the other hand, workers who stay in the same industry or occupation are more likely to retain their specific human capital and thus preserve their pre-unemployment productivity levels. In our study, however, we do not find strong supportive evidence of this. While the coefficients on CHNGED_IND and CHNGED_OCC have the expected negative sign, they are not statistically significant. One of the possible explanations may be the fact that our specification of the earnings equation assumes the same penalty for switching between any industries or occupations. However, the penalties for switching are likely to be different for different industries and occupations. According to Polachek (1981), there are high- and low-penalty jobs. The former are associated with large investments in firm-specific human capital, while the latter mostly require investments in general human capital. Since our analysis does not take into account these differences, it may lead to the statistically insignificant penalty coefficients. Further, it may be the case that any potential substantial earning losses for those who switched between industries and occupations may have been offset by different industry specific factors, such as pay schemes, unionization, the workings of internal labor markets, etc.

\section{Sector (Private Vs. Public) Of Employment}

We next focus in more detail on the sector of previous employment and the sector in which a new job is secured. The common belief is that the private sector attracts highly motivated, ambitious, energetic, and active people. Thus, the sector variable $C U R P R V$ in the wage equation may be viewed as a proxy for these unobservable characteristics; and the coefficient on this variable may be viewed as the return to them. The importance of private versus public sector as a segmenting force in the Polish labor market could be seen in the existence of sectoral wage premiums (see Adamchik and Bedi, 2000) as well as wage penalties associated with changing one's sector of employment after a jobless spell. Indeed, finding a new job in the private sector is estimated to raise the postunemployment wage for men in our sample by about 11 percent in comparison with those finding state sector jobs; however, for women there is no evidence of a private sector premium in the acceptance wage. Furthermore, while the acceptance wage seems to be negatively affected by transitions between the private and public sectors of the economy, the coefficients on CHNGED_SEC are not statistically significant. 
Why do we not find strong evidence of a private-public divide in the Polish labor market? We hypothesize that public-private segmentation did play a role at the beginning of the transition process but its influence diminished along with the growing private sector share in employment and output. The results presented in Table 2 show that for 1994-1996 we observe a significant wage premium in the private sector for both men and women as well as a significant wage penalty associated with changing one's sector of employment. To help sort out the effects of pre-and post-unemployment sector on post-unemployment wages in 1994-1996 we have calculated predicted wages from the regressions in Table 2 for men and women with mean characteristics and different combinations of pre- and postunemployment job sectors ( $\left.L A S T P R V, L A S T P U B, C H A N G E D \_S E C, C U R P R V\right)$. For men there were important wage advantages, on the order of 21-36 percent, to finding a private sector job after an unemployment spell in the 19941996 period. Women also gained by finding private sector jobs but the wage premium for them was lower than for men, on the order of 7-19 percent. The highest wages were earned by men and women who had a private sector job prior to an unemployment spell and were reemployed in the private sector. In contrast, in the 1997-2000 period, none of the coefficients on the variables reflecting the sector of the previous and current employment are statistically significant. It may be somewhat surprising that the private sector wage premium and the wage penalty for changing sectors seem to have evaporated in the late 1990s. However, the fact that a similar phenomenon has also been reported for all employees in Poland (Adamchik et al., 2003) gives additional support to our findings. We conclude that the private-public divide in the Polish labor market has been erased, possibly as a result of the massive privatization program and a consequent rapid growth in the private sector share of total employment, which doubled during the 1990s and surpassed 70 percent by 2000 .

\section{Returns To Human Capital And Gender}

The results discussed above clearly show that ceteris paribus, men and women experience different returns to accumulated human capital variables, which, in turn, implies that unemployment experience has a different impact on subsequent wages for men and women. The standard way of decomposing wage differences is to use the BlinderOaxaca methodology. As shown by Oaxaca and Ransom $(1994,1999)$, various decompositions of the mean wage gap between males $(m)$ and females $(f)$ may be expressed as

$$
\bar{X}_{m} \hat{\beta}_{m}-\bar{X}_{f} \hat{\beta}_{f}=\left(\bar{X}_{m}-\bar{X}_{f}\right) \hat{\beta}_{*}+\bar{X}_{m}\left(\hat{\beta}_{m}-\hat{\beta}_{*}\right)+\bar{X}_{f}\left(\hat{\beta}_{*}-\hat{\beta}_{f}\right)
$$

where $\bar{X}$ represents the means of observed characteristics, $\hat{\beta}$ is estimated coefficients, and $\hat{\beta}_{*}$ is the estimated nondiscriminatory wage structure. Consequently, the results of the decomposition may be quite sensitive to the choice of $\hat{\beta}_{*}$. We used $\hat{\beta}_{*}=\hat{\beta}_{m}$ in Decomposition (1), $\hat{\beta}_{*}=\hat{\beta}_{f}$ in Decomposition (2), $\hat{\beta}_{*}=\left(\hat{\beta}_{m}+\hat{\beta}_{f}\right) / 2$ in Decomposition (3), and $\hat{\beta}_{*}=\hat{\beta}_{p}$ in Decomposition (4). In the latter case, the estimated non-discriminatory wage structure $\hat{\beta}_{p}$ is obtained by estimating a regression over the pooled male-female sample (see Neumark, 1988).

The mean acceptance wage in logarithms was 5.511 for men and 5.363 for women. Decompositions 1-3 attribute all of the male-female difference in mean acceptance wages to differences in the male-female regression coefficients. The most conservative decomposition scheme 4 attributes 52 percent in the male-female mean $\log$ acceptance wage gap to differences in the male-female regression coefficients and 48 percent to differences in observed characteristics. Although their effect is small, the gender differences in educational attainment and in the proportion of individuals who switched between industries, occupations and sectors work towards reducing the malefemale wage gap, while the differences in potential experience and tenure are responsible for widening the wage gap.

This decomposition analysis supports the conclusion that, on average, men and women with identical observable characteristics do not receive the same wage offers in the post-unemployment job. As formally shown by Oaxaca and Ransom (1999), a detailed decomposition of the unexplained portion of the wage gap is problematic and depends upon the choice of the reference category. This sensitivity makes it difficult to assess the contribution of each factor. Given our specification of the wage equation, we may conclude that the returns to education and potential 
experience tend to favor women, the returns to tenure tend to favor men, and the penalties for switching between industries, occupations and sectors appear to reduce female wages while at the same time conferring a disadvantage upon men. While the exact source of the differences in returns is not clear, they may be due to unobserved qualities that increase the suitability of men or women for specific jobs, employers' tastes, etc.

\section{CONCLUSION}

This study analyzes the determinants of post-unemployment wages of those individuals who experienced a spell of unemployment in the period from 1994 to 2001 in Poland. Special emphasis is placed on the extent to which post-unemployment wages are determined by human capital accumulated before permanent job loss. The major empirical findings on the three specific issues listed in the Introduction may be summarized as follows:

- Educational attainment was an important factor of the acceptance wages of men and women. The positive and statistically significant coefficients indicate that the wage return to schooling was higher for workers with more education, with the rates of return to all educational levels being higher for women as compared to men. At the same time, we observe a noticeable reduction in the educational wage premia for women in the late 1990s.

- $\quad$ Potential labor market experience was a statistically significant determinant of acceptance wages only for women. On the other hand, job tenure prior to unemployment was a significant determinant of the postunemployment wage only for men. Thus, for men the results imply a partial transferability of job-specific human capital, although it seems that labor market experience accumulated prior to 1990 did not have any positive impact on post-unemployment wages while experience gained during the transition period did.

- Those individuals who found a new job in the same industry or occupation did not seem to earn higher postdisplacement earnings as compared to those who changed industry or occupation. Regarding the sector of employment (private versus public), the results present some evidence of a segmented labor market in the early years of transition, namely 1994-1996. During that period, the fairly large wage premium for finding work in the private sector after a spell of unemployment was enhanced for those who did not change sectors. However, it appears that the private sector wage premium as well as penalties for switching between the sectors evaporated in the late 1990s. Hence, we conclude that the private-public divide in the Polish labor market weakened as a consequence of rapid private job growth.

Finally, our analysis shows that the major portion of the male-female difference in the mean log acceptance wage gap is attributed to the differences in the male-female regression coefficients. Tenure (education) is the only human capital factor that consistently works towards increasing (reducing) the male-female wage gap, both in its explained and unexplained portions. The impact of potential work experience and switching between industries, occupations and sectors is mixed, that is simultaneously working towards increasing and reducing the wage gap.

\section{SUGGESTIONS FOR FUTURE RESEARCH}

The results suggest possible directions for future research. First, a noticeable reduction in the educational wage premia for women in the late 1990s seems to be an interesting topic, since the falling educational returns may discourage women from acquiring more education. In addition, it would be important to understand why the educational returns for women are falling while those for men rise. Second, our findings on different returns to experience and tenure warrant further research on the male-female differences in choosing how many and what kind of skills (general or job-specific) to acquire. Third, our finding of no significant penalties for switching industries and occupations should be re-tested by taking into consideration job characteristics. Fourth, a high unexplained portion of the male-female wage differential suggests that we need to take a closer look at workers' heterogeneity. 


\section{REFERENCES}

1. Adamchik, V. and Bedi, A. (2000). Wage Differentials between the Public and the Private Sectors: Evidence from an Economy in Transition, Labour Economics, Vol. 7, pp. 203-224.

2. $\quad$ Adamchik, V., Hyclak, T., and King, A. (2003). The Wage Structure and Wage Distribution in Poland, 19942001, International Journal of Manpower, Vol. 24, pp. 916-946.

3. Addison, J. and Portugal, P. (1989). Unemployment Insurance and Unemployment Spells, Southern Economic Journal, Vol. 56, pp. 166-182.

4. Boeri, T. (2001). Transition with Labour Supply, IZA Discussion Paper No. 257, Institute for the Study of Labor, Bonn.

5. Borland, J. (2000). Economic Explanations of Earnings Distribution Trends in the International Literature and Application to New Zealand, The New Zealand Treasury Working Paper No. 00/16, Melbourne.

6. Farber, H. (1997). The Changing Face of Job Loss in the United States: 1981-1995, Brookings Papers on Economic Activity: Microeconomics, pp. 55-128.

7. Greene, W. (1997). Econometric Analysis. MacMillan Publishing Company.

8. Greene, W. (1981). Sample Selection Bias as a Specification Error: Comment, Econometrica, Vol. 49, pp. 795-798.

9. Heckman, J. (1979). Sample Selection Bias as a Specification Error, Econometrica, Vol. 47, pp. 153-161.

10. Kletzer, L. (1989). Returns to Seniority After Permanent Job Loss, American Economic Review, Vol. 79, pp. 536-543.

11. Kletzer, L. (1998). Job Displacement, Journal of Economic Perspectives, Vol. 12, pp. 115-136.

12. Kriechel, B. and Pfann, G. (2005). The Role of Specific and General Human Capital After Displacement, Education Economics, Vol. 13, pp. 223-236.

13. McCall, J. (1970). The Economics of Information and Job Search, Quarterly Journal of Economics, Vol. 84, pp. 113-126.

14. Murphy, K. and Topel, R. (1985). Estimation and Inference in Two-Step Econometric Models, Journal of Business and Economic Statistics, Vol. 3, pp. 370-379.

15. Neal, D. (1995). Industry-Specific Human Capital: Evidence from Displaced Workers, Journal of Labor Economics, Vol. 13, pp. 653-677.

16. Neumark, D. (1988). Employers' Discriminatory Behavior and the Estimation of Wage Discrimination, Journal of Human Resources, Vol. 23, pp. 279-295.

17. Oaxaca, R. and Ransom, M. (1994). On Discrimination and the Decomposition of Wage Differentials, Journal of Econometrics, Vol. 61, pp. 5-21.

18. Oaxaca, R. and Ransom, M. (1999). Identification in Detailed Wage Decompositions, Review of Economics and Statistics, Vol. 81, pp. 154-157.

19. Polachek, S. (1981). Occupational Self-Selection: A Human Capital Approach to Sex Differences in Occupational Structure, Review of Economics and Statistics, Vol. 63, pp. 60-69.

20. Prasad, E. (2003). What Determines the Reservation Wages of Unemployed Workers? New Evidence from German Micro Data, IZA Discussion Paper No. 694, Institute for the Study of Labor, Bonn.

21. Schmidt, C. and Winkelmann, R. (1993). Reservation Wages, Wage Offer Distribution and Accepted Wages, in Panel Data and Labour Market Dynamics, Contributions to Economic Analysis, Vol. 222, Amsterdam: North-Holland, pp. 149-170.

22. Socha, M. and Weisberg, Y. (1999). Poland in Transition: Labor Market Data Collection, Monthly Labor Review, Vol. 122, pp. 9-21. 
APPENDIX 1: DEFINITIONS OF VARIABLES IN THE ACCEPTANCE WAGE EQUATION

\begin{tabular}{|c|c|c|}
\hline Characteristics & Variables & Description \\
\hline Marital status & MARRIED & Married. Reference: single, divorced, separated, widowed. \\
\hline Education & $\begin{array}{l}\text { HIGHER; SECVOC; SECGEN; } \\
\text { BASICVOC }\end{array}$ & $\begin{array}{l}\text { University and post-secondary; Secondary vocational; Secondary } \\
\text { general; Basic vocational. Reference: elementary or incomplete } \\
\text { elementary. }\end{array}$ \\
\hline Potential experience & POTEXP; POTEXPSQ & $\begin{array}{l}\text { Potential experience }=\text { Age }(\text { years }) \text {-Years of education }-6 \\
\text { Potential experience squared. }\end{array}$ \\
\hline $\begin{array}{l}\text { Duration of } \\
\text { unemployment }\end{array}$ & LnTUNEMPL & Log elapsed unemployment duration (months). \\
\hline $\begin{array}{l}\text { Reasons for being } \\
\text { unemployed }\end{array}$ & LOSER & $\begin{array}{l}\text { Fired. Reference: liquidation, quit, temporary work, retirement, or } \\
\text { never worked before. }\end{array}$ \\
\hline $\begin{array}{l}\text { Pre-unemployment } \\
\text { sector }\end{array}$ & LASTPUB; LASTPRV & $\begin{array}{l}\text { Last job in the public sector; Last job in the private sector. } \\
\text { Reference: never worked before. }\end{array}$ \\
\hline $\begin{array}{l}\text { Pre-unemployment } \\
\text { tenure }\end{array}$ & $\begin{array}{l}\text { TENURE1_4; TENURE5_9; } \\
\text { TENURE10_ }\end{array}$ & $\begin{array}{l}\text { 1-4 years; } 5-9 \text { years; } 10 \text { and more years. Reference: less than } 1 \\
\text { year or never worked before. }\end{array}$ \\
\hline $\begin{array}{l}\text { Post-unemployment } \\
\text { industry }\end{array}$ & \begin{tabular}{|l|} 
AGRIFISH; MINING; MANUF; \\
CONSTR; ENERTRANSP; \\
TRADEHOTEL; FINESTATE; \\
ADEDHEC
\end{tabular} & $\begin{array}{l}\text { Agriculture and fishing; Mining; Manufacturing; Construction; } \\
\text { Energy supply and transportation; Trade, hotels and restaurants; } \\
\text { Financial services and real estate; Public administration, education, } \\
\text { health care, community and social services. Reference: others. }\end{array}$ \\
\hline $\begin{array}{l}\text { Post-unemployment } \\
\text { occupation }\end{array}$ & $\begin{array}{l}\text { TOPMANAGER; SPECIALIST; } \\
\text { TECHNICIAN; OFFICE; SERVICE; } \\
\text { FARMER; INDUSTRIAL; MACHINIST }\end{array}$ & $\begin{array}{l}\text { Top manager; Specialist; Technician; Office employee; Services; } \\
\text { Farmer; Industrial worker; Machinist. Reference: manual worker. }\end{array}$ \\
\hline $\begin{array}{l}\text { Type of post- } \\
\text { unemployment job }\end{array}$ & PERMAN & Permanent job. Reference: temporary job. \\
\hline $\begin{array}{l}\text { Firm size at post- } \\
\text { unemployment job }\end{array}$ & $\begin{array}{l}\text { SIZE6_20; SIZE21_50; SIZE51_100; } \\
\text { SIZE100_ }\end{array}$ & $\begin{array}{l}\text { 6-20 employees; } 21-50 \text { employees; } 51-100 \text { employees; More than } \\
100 \text { employees. Reference: } 5 \text { or less employees. }\end{array}$ \\
\hline $\begin{array}{l}\text { Sector of post- } \\
\text { unemployment job }\end{array}$ & CURPRV & Private sector. Reference: public sector. \\
\hline $\begin{array}{l}\text { Changed sector of } \\
\text { employment }\end{array}$ & CHNGED_SEC & $\begin{array}{l}\text { Changed the sector (private vs. public) of employment. Reference: } \\
\text { did not change the sector of employment or never worked before. }\end{array}$ \\
\hline $\begin{array}{l}\text { Changed industry of } \\
\text { employment }\end{array}$ & CHNGED_IND & $\begin{array}{l}\text { Changed the industry of employment. Reference: did not change } \\
\text { the industry of employment or never worked before. }\end{array}$ \\
\hline Changed occupation & CHNGED_OCC & $\begin{array}{l}\text { Changed occupation. Reference: did not change the occupation or } \\
\text { never worked before. }\end{array}$ \\
\hline $\begin{array}{l}\text { Regional } \\
\text { unemployment rate }\end{array}$ & LnURATE & Log regional unemployment rate $(\%)$ \\
\hline Place of residence & CITY100_; CITY20_100; CITY_20 & $\begin{array}{l}\text { City }(>100,000 \text { residents }) \text {; city }(20,000-100,000 \text { residents }) \text {; city } \\
(<20,000 \text { residents). Reference: town or rural area. }\end{array}$ \\
\hline Year & $\begin{array}{l}\text { Y1995; Y1996; Y1997; Y1998; Y1999; } \\
\text { Y2000 }\end{array}$ & 1995; 1996; 1997; 1998; 1999; 2000. Reference: 1994. \\
\hline Season & SPRSUM & Spring or summer. Reference: autumn or winter. \\
\hline
\end{tabular}




\section{APPENDIX 2: VARIABLES IN THE RESERVATION WAGE EQUATION}

- $\quad$ Dependent variable is the log real net monthly reservation wage.

- $\quad$ Marital status; Education; Age and Age squared; Position in the household; Main and additional sources of personal and household income while unemployed; Duration of unemployment; Reasons for looking for a job; Willingness to accept changes with a new job; Job search methods; Pre-unemployment sector (public vs. private), tenure, industry and occupation; Regional unemployment rate; Place of residence; Year; Season.

- The number of observations is 19,047 for men and 19,907 for women. The variables that affect an individual's reservation wage but do not have any impact on employers' decision to hire, that is, $K_{2}$ in Eq. (3a), consist of four groups of dummy variables describing main and additional sources of both personal and household income.

\section{APPENDIX 3: VARIABLES IN THE PROBIT EQUATION}

- $\quad$ Dependent variable is the index of the labor market state to which the exit from unemployment has occurred: $0=$ not in the labor force, $1=$ unemployed, $2=$ part-time hired employee, $3=$ assisting family member in a family business, 4 = self-employed, 5 = full-time hired employee.

- $\quad$ Marital status; Education; Age and Age squared; Position in the household; Duration of unemployment; Reasons for looking for a job; Willingness to accept changes with a new job; Job search methods; Preunemployment sector (public vs. private), tenure, industry and occupation; Regional unemployment rate; Place of residence; Year; Season; LnRW_HAT; $\mathrm{Mu}(1) ; \mathrm{Mu}(2) ; \mathrm{Mu}(3) ; \mathrm{Mu}(4)$.

- $\quad$ The number of observations is 19,047 for men and 19,907 for women.

- With included predicted reservation wages, the coefficients on other regressors in the probit equation, that is, Eq. (3-b), are supposed to capture demand factors alone.

We also experimented with the probit equation without the reservation wage. In this specification, the coefficients represent the combined effect of both demand and supply factors (that is, job offer and acceptance factors) on the labor market status. Generally, the estimated coefficients were lower than those with predicted reservation wages. The interpretation could be as follows. For example, high education has a positive effect on both the arrival rate of job offers and the reservation wage. Given that the reservation wage reduces the acceptance rate, the effect of high education on the probability of getting a job is lower than the effect of high education on the probability of getting an offer.

We also experimented with both ordered and unordered logit as our selection equation. The ordered probit and ordered logit models produce similar results. The MNL approach is computationally cumbersome because our model quickly becomes very large one since the outcome variable takes on many values. 